\title{
ABOVEGROUND BIOMASS ESTIMATION IN A TROPICAL FOREST WITH SELECTIVE LOGGING USING RANDOM FOREST AND LIDAR DATA
}

\author{
Juliana Marchesan ${ }^{*}$, Elisiane Alba ${ }^{2}$, Mateus Sabadi Schuh ${ }^{3}$, José Augusto Spiazzi Favarin ${ }^{4}$, Rudiney Soares \\ Pereira $^{5}$ \\ ${ }^{1 *}$ Federal University of Santa Maria, Postgraduate Program in Forest Engineering, Santa Maria, Rio Grande do Sul, Brazil - \\ marchesan.ju@gmail.com \\ ${ }^{2}$ Federal Rural University of Pernambuco, Academic Unit of Serra Talhada, Serra Talhada, Pernambuco, Brazil - elisianealba@ gmail.com \\ ${ }^{3}$ Federal University of Santa Maria, Postgraduate Program in Forest Engineering, Santa Maria, Rio Grande do Sul, Brazil - \\ mateuschuh@gmail.com \\ ${ }^{4}$ Federal University of Paraná, Postgraduate Program in Forest Engineering, Curitiba, Paraná, Brazil - jaspiazzi@gmail.com \\ ${ }^{5}$ Federal University of Santa Maria, Rural Engineering Department, Santa Maria, Rio Grande do Sul, Brazil - rudiney.s.pereira@ gmail.com
}

Received for publication: 30/04/2019 - Accepted for publication: 14/10/2019

\begin{abstract}
Resumo
Estimativa de biomassa acima do solo em floresta tropical com extração seletiva utilizando Random Forest e dados LiDAR. A floresta tropical é caracterizada pela biomassa expressiva e, dessa forma, armazena alta quantidade de carbono, sendo esta uma variável importante para o monitoramento climático. Com isso, são cruciais estudos que visem analisar métodos adequados para a predição da biomassa, principalmente nos trópicos, onde a vegetação densa dificulta a modelagem. Assim, o objetivo do estudo foi estimar a biomassa acima do solo em área de floresta tropical com extração seletiva localizada na floresta Amazônica utilizando o algoritmo de aprendizado de máquina Random Forest (RF) e dados LiDAR. Para tal, foram utilizadas 85 unidades amostrais dispostas na Fazenda Cauaxi, no município de Paragominas, Pará. Os dados LiDAR foram coletados em 2014 e disponibilizados pelo projeto Paisagens Sustentáveis Brasil. O Software R foi utilizado para análise dos dados. Dentre as métricas LiDAR, a altura média foi a que obteve maior significância para compor o modelo, sendo a selecionada para o mesmo. O modelo apresentou um pseudo $\mathrm{R}^{2}$ de 0,69 (valor obtido pelo RF) e Coeficiente de Correlação de Spearman de 0,80, o RMSE foi de 47,05 Mg.ha ${ }^{-1}$ (19,84\%) e o Bias de 2,06 Mg.ha ${ }^{-1}(0,87 \%)$. Com os resultados foi possível inferir que a métrica da altura média se apresentou adequada para estimar biomassa acima do solo em floresta tropical com extração seletiva, além disso, o algoritmo RF permitiu estimar a biomassa, podendo o mesmo ser utilizado para auxiliar no monitoramento e ações de manejo em áreas de extração seletiva, além de servir de base para políticas de mitigação de mudanças climáticas.
\end{abstract}

Palavras-chave: Floresta Amazônica; sensoriamento remoto; aprendizado de máquina.

\section{Abstract}

The tropical forest is characterized by expressive biomass and stores high amounts of carbon, which is an important variable for climate monitoring. Thus, studies aiming to analyze suitable methods to predict biomass are crucial, especially in the tropics, where dense vegetation makes modeling difficult. Thus, the objective of the present study was to estimate aboveground biomass (AGB) in a tropical forest area with selective logging in the Amazon forest using the Random Forest (RF) machine learning algorithm and LiDAR data. For this, 85 sample units were used at Fazenda Cauaxi, in the municipality of Paragominas, Pará State. LiDAR data were collected in 2014 and made available by the Sustainable Landscapes Project. The software R was used for data analysis. Among the LiDAR metrics, the average height was used as it had the greatest significance to compose the model. The model presented a pseudo $\mathrm{R}^{2}$ of 0.69 (value obtained by the RF), Spearman's Correlation

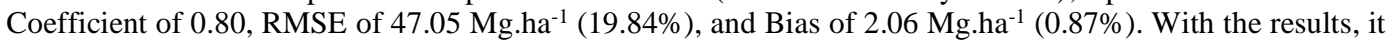
was possible to infer that the average height metric was enough to estimate AGB in a tropical forest with selective logging, in addition, the RF algorithm the biomass to be estimated, which can be used to assist in monitoring and action management in areas of selective logging and serve as a basis for climate change mitigation policies.

Keywords: Amazon rainforest; remote sensing; machine learning.

\section{INTRODUCTION}

Tropical forests are one of the most biodiverse habitats known and cover $45 \%$ of the total forest area of the world (D'ANNUNZIO et al., 2017). These biomes represent two-thirds of the total terrestrial area of the planet and are characterized by expressive biomass and storing high amounts of carbon (PAN et al., 2013). Despite their importance, tropical forests have been destroyed at a rapid pace, with the forest typology having lost the largest area (D'ANNUNZIO et al., 2017). Among tropical forests, the Amazon rainforest has experienced the most deforestation (ISU, 2015), as selective logging in recent years has resulted in the widespread logging of large trees.

FLORESTA, Curitiba, PR, v. 50, n. 4, p. 1873 - 1882, out/dez 2020.

Marchesan, J. et.al.

ISSN eletrônico 1982-4688

DOI: $10.5380 /$ rf.v50 i4. 66589 
Selective logging contributes to carbon flux and influences the fragmentation of the remnants (ASNER et al., 2009). In this context, estimating biomass makes it possible to determine carbon emissions caused by deforestation and analyze the impacts of selective logging. Quantifying carbon is fundamental to develop forest monitoring systems and implement climate change mitigation policies, such as the program for Reducing Emissions from Deforestation and Forest Degradation (REDD+) (GARCIA et al., 2017).

Measuring AGB in tropical forests is costly due to extensive and difficult-to-access areas. In these conditions, advances in remote sensing have allowed for the mapping and monitoring of such regions, making it possible to obtain reliable information within short periods (ALVES et al., 2013).

Selective logging is characterized by the cutting of large trees, which, unlike deforestation, causes diffuse thinning and makes monitoring even more difficult (ASNER et al., 2009). Thus, LiDAR (Light Detection and Ranging) technology stands out as it allows detailed information on vegetation to be obtained and accurately estimates biophysical variables (KUMAR; MUTANGA, 2017) since they correlate with the metrics derived from LiDAR data (LI et al., 2017).

Therefore, several studies have been carried out to predict different biophysical variables, including aboveground biomass (AGB), in which research has demonstrated the capacity of LiDAR data to estimate this variable in different ecosystems (D'OLIVEIRA et al., 2012; GARCIA et al., 2017; HANSEN et al., 2015). However, further studies are required to evaluate the methods of estimating AGB in tropical forest areas because, due to dense vegetation, errors in modeling may occur (D'OLIVEIRA et al., 2012). Thus, research aimed at analyzing the different AGB prediction methods is crucial to verify which are suitable for each forest typology.

AGB can be measured through data from remote sensing techniques using parametric and non-parametric methods. However, flexible methods have become more common in recent years, often being non-parametric (SHAO; ZHANG, 2016). Among such methods, the Random Forest (RF) machine learning algorithm stands out and has been used in several studies (HUDAK et al., 2012; LI et al., 2017). Machine learning algorithms are an alternative to parametric methods since they can be used when the data are heterogeneous and do not present normality, as is the case with tropical forests (MONTAÑO et al., 2017).

Given the above, LiDAR data allow for the gathering of AGB estimates, although further studies are required to assess their use to estimate tropical forests. Thus, the objective of this study was to estimate the AGB of a tropical forest area with selective logging located in the Amazon forest by using the RF machine learning algorithm and LiDAR data.

\section{MATERIAL AND METHODS}

\section{Study area location and characterization}

The study area comprises Fazenda Cauaxi, which is located in the municipality of Paragominas (Pará State, Brazil; Figure 1), and located between the UTM coordinates 9583090 and $9587407 \mathrm{mN}$, and 778074 and $781384 \mathrm{mE}$ west of the Central Meridian ( $\left.51^{\circ}\right)$, Zone $22 \mathrm{~S}$, totaling 1,216 ha.

The area under study is divided into twelve logging units, ten of which have been registered as reducedimpact logging areas since 2007 (SILVA et al., 2017a). The Tropical Forest Institute (IFT) has been carrying out forestry activities at Fazenda Cauaxi since 1995. The predominant forest typology is the Dense Ombrophilous Forest and is characterized by having perennial and rarely deciduous trees, high biomass, and closed canopy. The climate is humid, with an average annual rainfall of 2,200 $\mathrm{mm}$ and an average annual temperature of approximately $25{ }^{\circ} \mathrm{C}$ (ALVAREZ et al., 2013).

\section{Field Data}

Twenty-two transects $(20 \times 500 \mathrm{~m})$ were randomly stratified in the study area in 2012 , and 88 sample units $(50 \times 50 \mathrm{~m})$ were spaced at $100 \mathrm{~m}$ intervals along the transects in 2014 . Subunits $(5 \times 50 \mathrm{~m})$ were stratified in each sample unit. The coordinates of the sample units were obtained by differential GNSS (Global Navigation Satellite System) (GeoXH6000, Trimble Navigation, Ltd.).

In the sample units, trees with $\mathrm{DBH} \geq 35 \mathrm{~cm}$ were measured, while all trees with $\mathrm{DBH} \geq 10 \mathrm{~cm}$ were measured in the subunits, totaling 1,793 trees measured. Three sample units were excluded from the analysis, as they were not included by the LiDAR coverage due to the overflight not encompassing the entire extent measured in the inventory. 


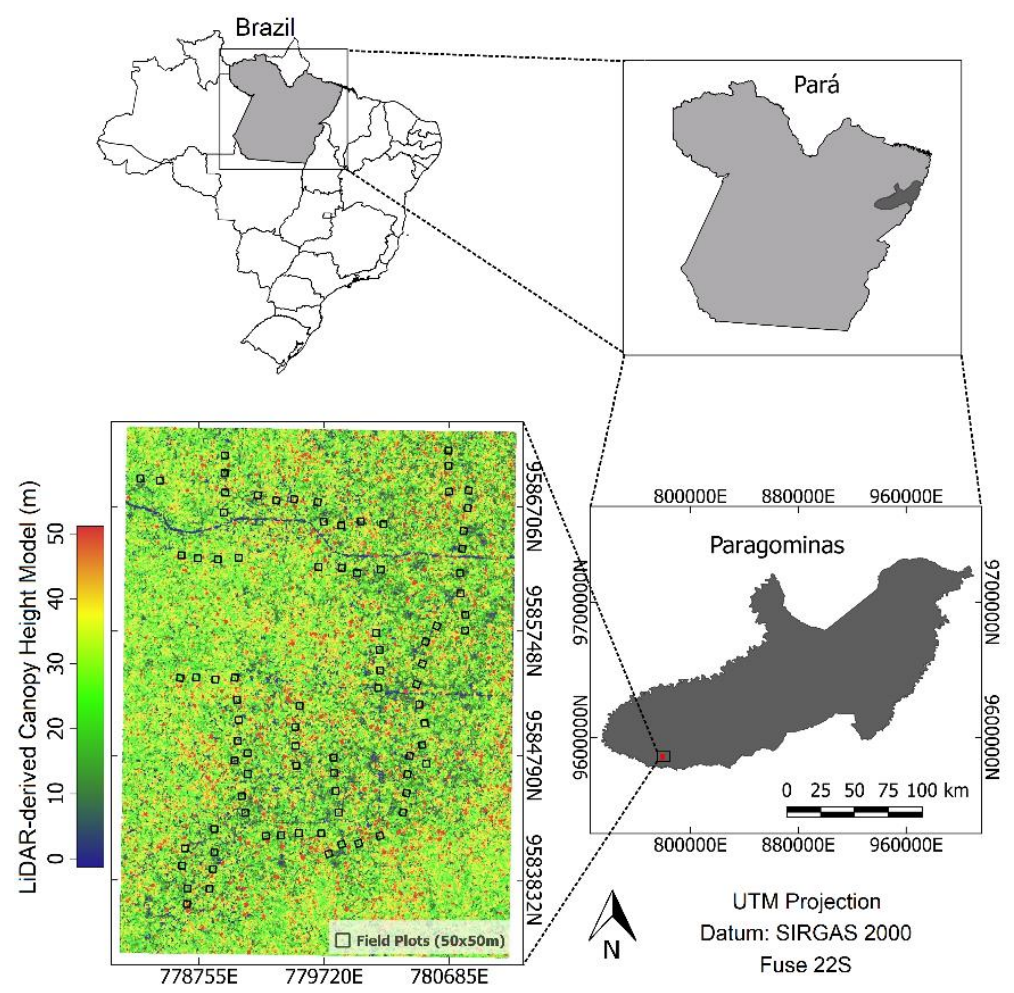

Figure 1. Location of the study area at Fazenda Cauaxi, Paragominas, Pará State, Brazil. Figura 1. Localização da área de estudo na Fazenda Cauaxi, Paragominas, Pará, Brasil.

The AGB of each tree was estimated by using the equation created by Chave et al. (2014). As described by the authors, the pantropical equation was elaborated using 4,004 trees located in tropical regions (Latin America, Afro-tropical areas, and Southeast Asia and Australia), totaling 58 tree collection sites. Thus, the model generated contributed to improving the accuracy of the tropical vegetation biomass.

$$
\left.\operatorname{AGB}(\mathrm{Kg})=\exp \left[-1.803-0.97 \mathrm{E}+0.976 \ln (\rho)+2.673 \ln (\mathrm{DBH})-0.0299[\ln (\mathrm{DBH})]^{2}\right)\right]
$$

Where: AGB (kg) is the living aboveground biomass in $\mathrm{kg}$; DBH is the diameter at breast height (measured $1.3 \mathrm{~m}$ above ground level) in $\mathrm{cm}$; $\mathrm{E}$ is a measure of environmental stress $(\mathrm{E}=-0.103815)$, and $\rho$ is the basic density of the wood in $\mathrm{kg} . \mathrm{m}^{-3}$. The total biomass for each sample unit was obtained by adding the biomass of the sample units

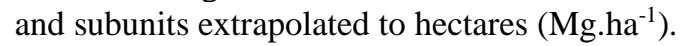

\section{LiDAR data and processing}

LiDAR data were collected at Fazenda Cauaxi in 2014 by using a scanner (Optech ORION M300) with an emission capacity of 37.5 laser pulses per square meter of area. The coverage area of the overflight was 1,216 ha. The data were acquired by the Sustainable Landscapes Project (https://www.paisagenslidar.cnptia.embrapa.br/webgis/), which was developed in partnership between the Brazilian Agricultural Research Corporation (EMBRAPA) and the United States Forest Service.

LiDAR data were processed using the software Fusion/LDV version 3.6. Pulse density was normalized using ThinData, which randomly reduces the number of pulses according to the desired size. The Catalog tool was used to evaluate the quality of the data, which is one of the initial stages of processing. The GroundFilter tool was used to filter the point cloud located on the terrain surface, with which it was possible to generate the Digital Terrain Model (DTM) through the GridSurfaceCreate tool with a spatial resolution of $1.0 \mathrm{~m}$. Then, the points were normalized using the ClipData tool, DTM switches, and minimum and maximum height in order to ensure that the height corresponded to the one above the ground. With the CanopyModel tool, the Canopy Height Model (CHM) was generated with a resolution of $1.0 \mathrm{~m}$. The sampling units were cut by using the PolyClipData tool and the metrics derived from the data were gathered for each sample unit of interest by using the CloudMetrics tool.

FLORESTA, Curitiba, PR, v. 50, n. 4, p. 1873 - 1882, out/dez 2020.

Marchesan, J. et.al.

ISSN eletrônico 1982-4688 


\section{AGB modeling}

To estimate AGB, it was necessary to select the most important LiDAR metrics for modeling. For this purpose, the RF algorithm was first used to demonstrate the importance value of each variable. Afterwards, the Model Improvement Ratio (MIR) method was used as a criterion to select the most relevant metrics, as it calculates the importance value based on standardized variables (MURPHY et al., 2010). This way, the metrics that yielded the highest MIR values were selected to compose the model. When the selected predictor variables showed a high correlation with each other ( $\mathrm{r}>0.9$ ), as proposed by Hudak et al. (2012), only one of the variables remained, eliminating the others (SILVA et al., 2017b). The software R (version 3.5.0) was used for data analysis.

Due to the non-normal data distribution verified by the Shapiro-Wilk normality test, non-parametric regression was chosen to obtain the AGB estimate in the study area. Thus, the RF machine learning algorithm was used as it allows a high set of sample trees to be integrated based on a deterministic technique. For this, the algorithm randomly selects a set of variables (SHAO; ZHANG, 2016) and divides the nodes of each tree using the best variables from a random sample.

Therefore, the randomForest package, which is available in $\mathrm{R}$, was used for running the algorithm, requiring the definition of two parameters: $m$ try, which corresponds to the number of variables randomly sampled as candidates for each division, using the standard value for regression of $\mathrm{p} / 3$, where $p$ is the number of variables; and ntree, which refers to the total number of trees (500) to be added to the model, as it was the one best suited for the data.

The model fit was evaluated by using Spearman's Correlation coefficient (r) due to the non-normality of the training data, Pseudo Coefficient of Determination (Pseudo $\mathrm{R}^{2}$ ), given directly by the RF model, Root Mean Square Error (RMSE), and absolute and relative bias.

The results were validated by using $20 \%$ of the data and the remaining $80 \%$ used to train the algorithm. The validation was done by the paired Wilcoxon test, being possible to evaluate whether the predicted and observed values differed significantly with a $95 \%$ significance level. The methodological procedures performed in this study can be viewed in the flowchart (Figure 2).
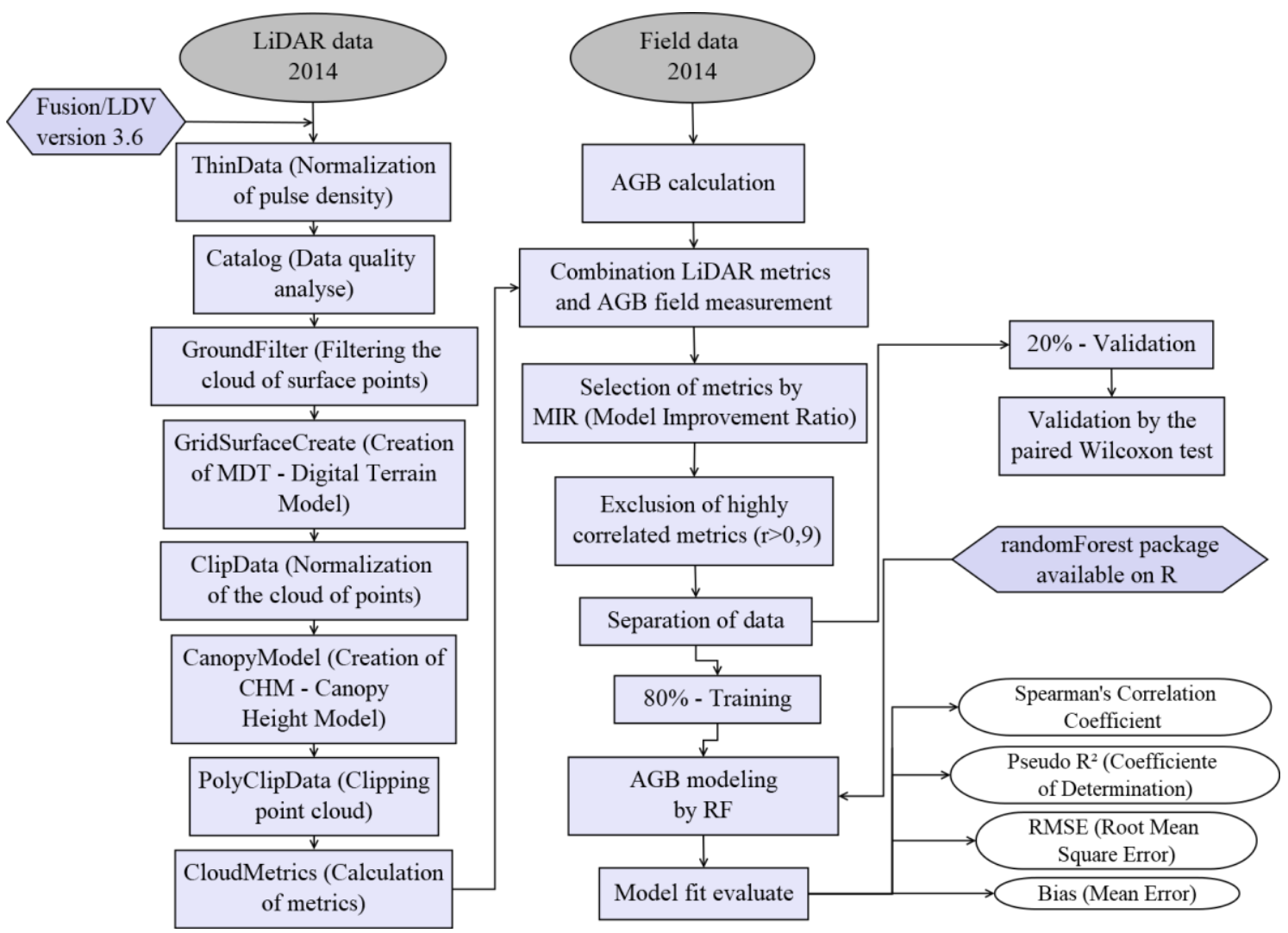

Figure 2. Methodological procedures to obtain AGB.

Figura 2. Procedimentos metodológicos para obtenção da biomassa acima do solo.

FLORESTA, Curitiba, PR, v. 50, n. 4, p. 1873 - 1882, out/dez 2020

Marchesan, J. et.al.

ISSN eletrônico 1982-4688 


\section{RESULTS}

\section{Variable selection}

With the calculation of the AGB for the 85 sample units under study, the lowest value was $61.46 \mathrm{Mg}$.ha-

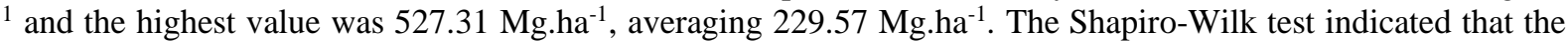
data did not show normality ( $\mathrm{p}$-value $=0.0058$ ), which is due to the discrepancy between the AGB values obtained in the sample units as a result of the existence of gaps in certain areas combined with sampling units with dense vegetation. A comparison of two different areas located at Fazenda Cauaxi is shown in Figure 3. The first area (Figure 3a) is characterized by the presence of gaps, with sparse trees and some larger ones, while the forest is denser in the second area (Figure $3 \mathrm{~b}$ ) with a predominance of large trees.
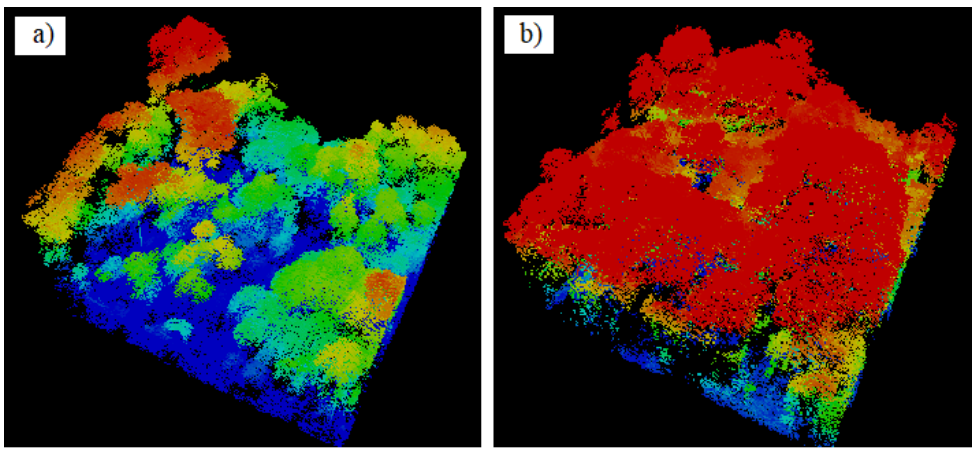

Figure 3. Comparison of two areas located at Fazenda Cauaxi: one with gaps (a) and the other with dense vegetation (b).

Figura 3. Comparação de duas áreas localizadas na Fazenda Cauaxi, Paragominas, Pará, uma com presença de clareiras (a) e outra com vegetação densa (b).

By processing the LiDAR point cloud in the Fusion/LDV Software, 87 metrics were obtained for each sample unit, which are statistical parameters that use the intensity and elevation of the points (MCGAUGHEY, 2018). The metrics with the highest correlation with AGB in the study area are described in Table 1.

Table 1. Spearman's correlation coefficient between AGB and metrics derived from LiDAR data.

Tabela 1. Correlação de Spearman entre a biomassa acima do solo e as métricas derivadas dos dados LiDAR.

\begin{tabular}{llr}
\hline Variable & LiDAR metrics ${ }^{(1)}$ & Spearman's Correlation $(\mathbf{r})(2)$ \\
\hline Hmean & Height mean & $0.83^{* * *}$ \\
HL1 & Height in the moment 1 & $0.83^{* * *}$ \\
HQmean & Height quadratic mean & $0.79^{* * *}$ \\
HP30 & Height 30th percentile & $0.78^{* * *}$ \\
HP25 & Height 25th percentile & $0.77^{* * *}$ \\
HP40 & Height 40th percentile & $0.77^{* * *}$ \\
HP50 & Height 50th percentile & $0.77^{* * *}$ \\
HP60 & Height 60th percentile & $0.75^{* * *}$ \\
HP20 & Height 20th percentile & $0.74^{* * *}$ \\
HCmean & Height cubic mean & $0.74^{* * *}$ \\
HP70 & Height 70th percentile & $0.71^{* * *}$ \\
HP75 & Height 75th percentile & $0.68^{* * *}$ \\
HP80 & Height 80th percentile & $0.66^{* * *}$ \\
HP10 & Height 10th percentile & $0.62^{* * *}$ \\
CRR & Canopy relief ratio & $0.57^{* * *}$ \\
HP90 & Height 90th percentile & $0.56^{* * *}$ \\
HP05 & Height 05th percentile & $0.53^{* * *}$ \\
HCV & Height coefficient of variation & $-0.51^{* * *}$ \\
Hmode & Height mode & $0.50^{* * *}$ \\
HP95 & Height 95th percentile & $0.50^{* * *}$ \\
HP01 & Height 01th percentile & $0.44^{* * *}$ \\
HP99 & Height 99th percentile & $0.42^{* * *}$ \\
HL4 & Height in the moment 4 (Kurtosis) & $0.42^{* * *}$ \\
AllRet & All returns above the mean & $0.42^{* * *}$ \\
HSK & Height skewness & $-0.40^{* * *}$ \\
PRet & Percentage of all returns above the mean height & $0.39^{* * * *}$ \\
HL3 & Height in the moment 3 (Skewness) & $-0.38^{* * *}$ \\
PFirstRet & Percentage of first returns above the mean height & $0.36^{* * * *}$ \\
\hline
\end{tabular}

FLORESTA, Curitiba, PR, v. 50, n. 4, p. 1873 - 1882, out/dez 2020.

Marchesan, J. et.al.

ISSN eletrônico 1982-4688

DOI: $10.5380 /$ rf.v50 i4. 66589 
${ }^{(1)}$ LiDAR metrics derived from the processing of the point cloud in the Fusion/LDV Software for the sample units. The metrics represent the height of the points in the study area; ${ }^{(2)}$ Only the LiDAR metrics with significant Spearman's correlation coefficient; *** p-value < 0.001.

The variable importance plot obtained by the RF algorithm is shown in Figure 4. The importance value is represented on the $\mathrm{x}$-axis for each LiDAR metric (y-axis) with significant Spearman's correlation ( $p$-value $<0.001$ ) with AGB. Thus, via the graph, it was possible to infer that the metrics of mean height (Hmean) and height in the moment 1 (HL1) were the ones that yielded the highest importance value, followed by the height quadratic mean (HQmean).

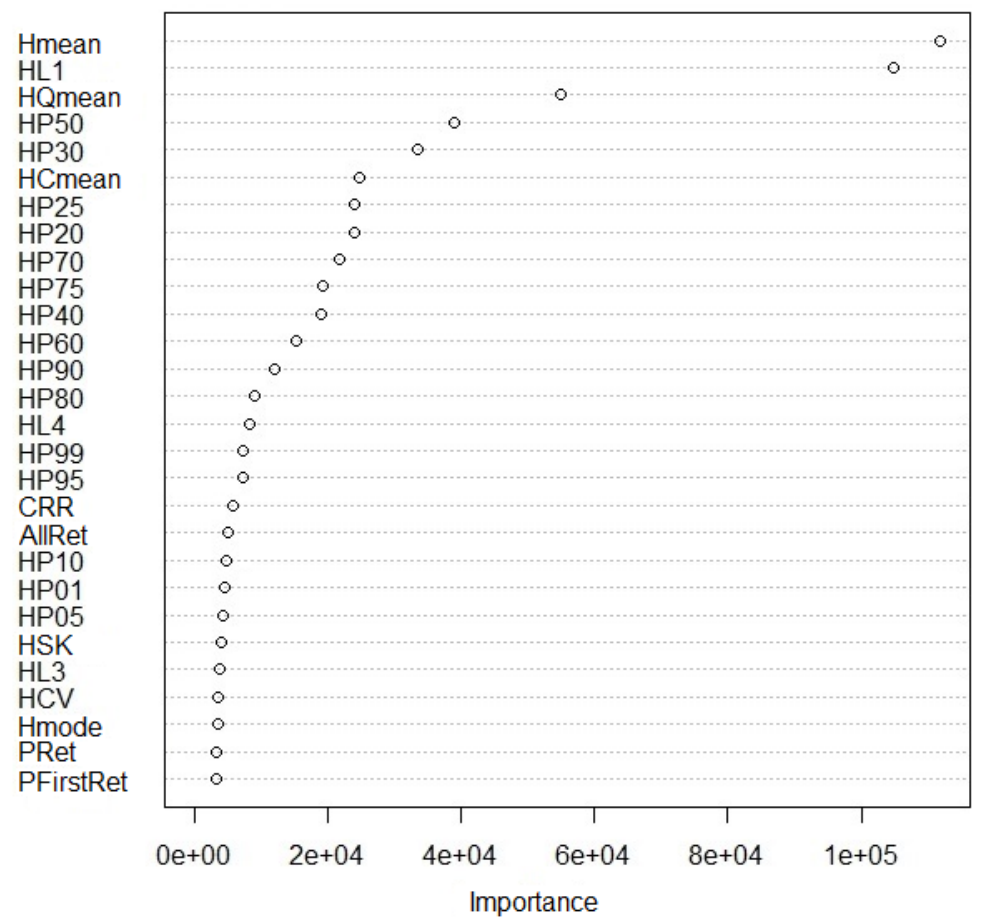

Figure 4. The candidate variables to compose the model and their respective importance according to the RF algorithm.

Figura 4. As variáveis candidatas a comporem o modelo e sua respectiva importância de acordo com o algoritmo RF.

By using the MIR value found for each metric, it was possible to select the mean height (Hmean), height in the moment 1 (HL1), and the height quadratic mean (HQmean) as the most important to compose the model. However, the first two were highly correlated ( $r>0.9$ ), since HL1 also refers to the mean height. Therefore, Hmean was kept as a predictor variable. HQmean did not influence the improvement of the model performance, therefore, it was excluded.

\section{AGB modeling}

The RF model using the Hmean metric yielded a Pseudo $\mathrm{R}^{2}$ of 0.69 and a Spearman's correlation coefficient of 0.80 with the AGB obtained in the field. Considering the error found, the RMSE was 47.05 Mg.ha'

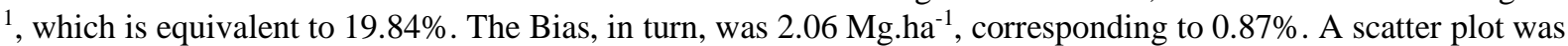
created (Figure 5a) in order to visualize the adjustment between the AGB obtained in the field and the LiDAR point cloud data.

To corroborate the results, the residual plot was generated (Figure 5b). The RF model showed residue of the positive and negative amplitude of approximately $150 \mathrm{Mg} \cdot \mathrm{ha}^{-1}$, thereby corroborating the dispersion plot, in which it is possible to observe that overestimated values occurred in some sample units and underestimated ones occurred in others.

The Wilcoxon test demonstrated that the estimated and observed values did not differ significantly (pvalue $=0.5171$ ) since it was higher than the acceptance threshold of 0.05 . In addition, it is possible to view the scatter plot between the estimated and observed values of the sample validation units (Figure 6). Visually, through the scatter plot (Figure 6a) and density plot (Figure 6b), it was noted that the AGB values found in the field (observed AGB) were similar to those obtained using the RF algorithm (estimated AGB), corroborating the result obtained by the Wilcoxon test.

FLORESTA, Curitiba, PR, v. 50, n. 4, p. 1873 - 1882, out/dez 2020

Marchesan, J. et.al. 

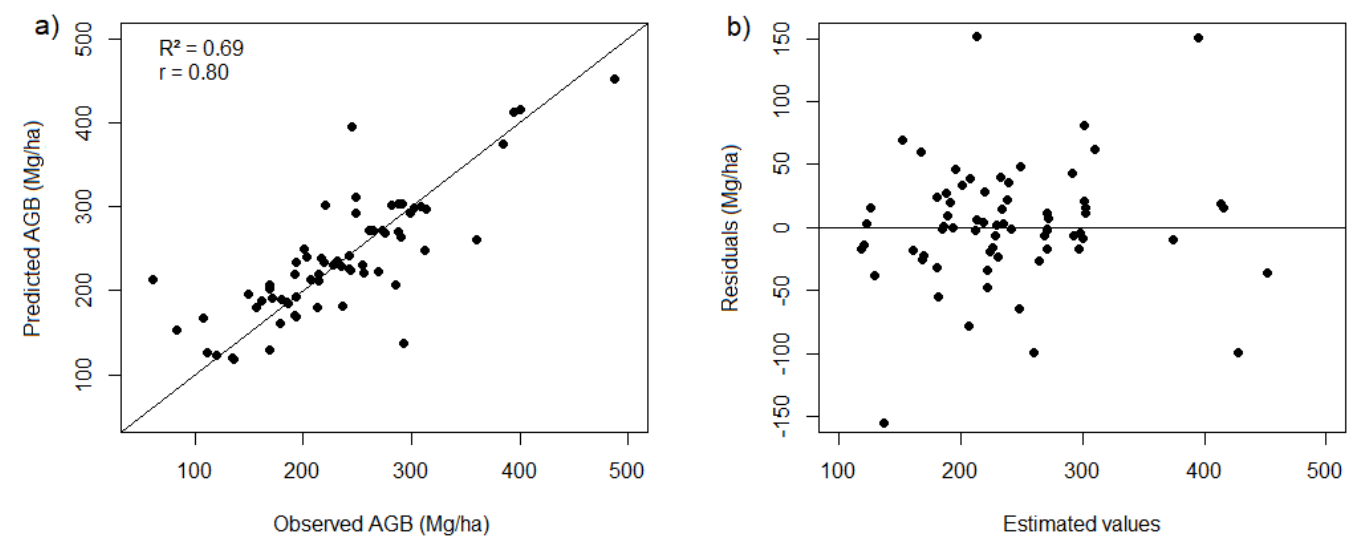

Figure 5. Scatter plot of predicted and observed AGB values (a) and residual distribution (b) for the RF model using LiDAR data.

Figura 5. Gráfico de dispersão dos valores preditos e observados da biomassa acima do solo (a) e distribuição dos resíduos (b) para o modelo RF utilizando dados LiDAR.
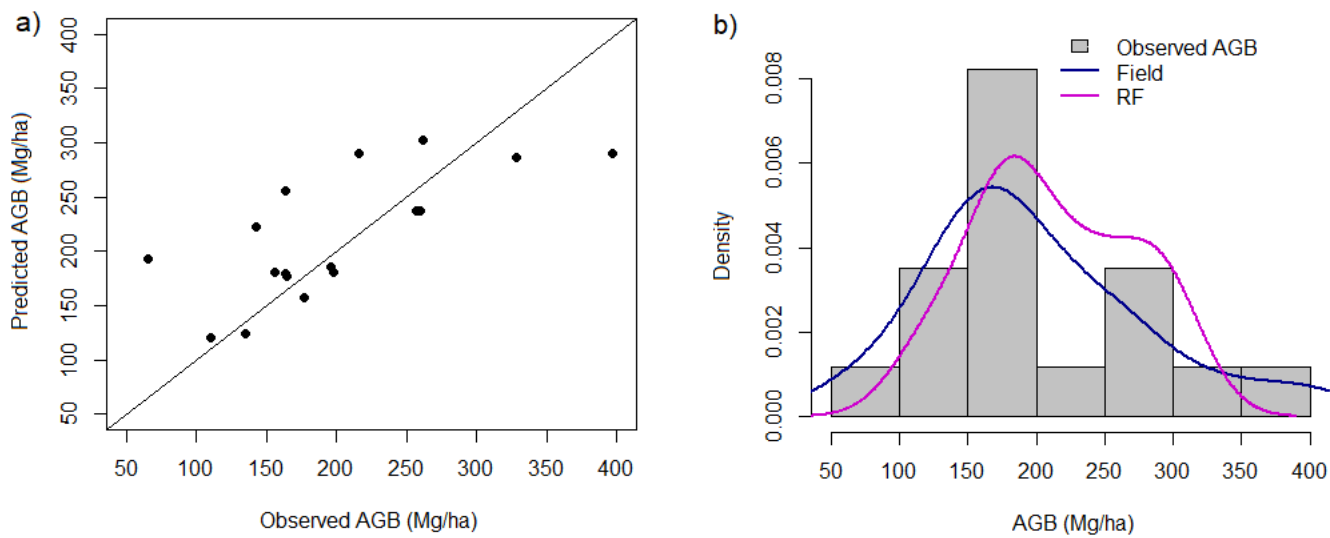

Figure 6. Scatter (a) and density (b) plot between the predicted and observed values using the validation samples in the RF model.

Figura 6. Gráfico de dispersão (a) e de densidade (b) entre os valores preditos e observados utilizando as amostras de validação no modelo RF.

\section{DISCUSSION}

The AGB values found in the study area were similar to those found in other areas located in the same

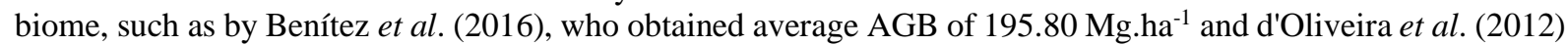
and Andersen et al. (2014), who analyzed regions of the Amazon biome with selective logging and found AGB

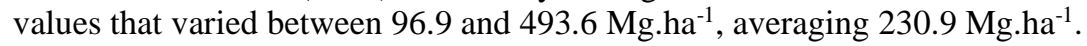

Among the LiDAR metrics obtained, those related to tree height were the ones that showed the highest correlation with AGB, with the average height being used to compose the model. Hansen et al. (2015) highlighted that of the metrics from the LiDAR point cloud, the average height is one of the most used for predicting AGB in tropical forests. Moreover, d'Oliveira et al. (2012) found one of the best adjustments for the average height, of the metrics tested, to estimate AGB in tropical forest areas. In addition, Silva et al. (2017a) used this metric to estimate the stock and changes in AGB in different DTM scenarios and pulse densities in the same field of study as the present work and found satisfactory results.

The model adjustment yielded by the RF algorithm was similar to other studies carried out in tropical forest areas. While using a multiple regression model with $\mathrm{R}^{2}$ of 0.70 and RMSE of $41.50 \mathrm{Mg}$.ha ${ }^{-1}$, Andersen et al. (2014) analyzed selective logging areas in the Amazon with LiDAR data and reported values close to those acquired here. Further corroborating the results found here, Silva et al. (2017a) obtained an $\mathrm{R}^{2}$ varying between 0.60 and 0.73 and an RMSE between 18.81 and $22.80 \%$ depending on the scenario and pulse density used, although the authors used parametric regression. Clark et al. (2011) also found similar RMSE values (38.30 Mg.ha $\left.{ }^{-1}\right)$ when using two metrics, average and maximum height. Given the above, it was possible to infer that the RF algorithm combined with LiDAR data yielded good estimates of AGB in tropical forest areas with selective logging.

FLORESTA, Curitiba, PR, v. 50, n. 4, p. 1873 - 1882, out/dez 2020

Marchesan, J. et.al.

ISSN eletrônico 1982-4688

DOI: 10.5380/rf.v50 i4. 66589 
However, by analyzing the scatter plot of the validation samples, a trend in the RF model can be noticed, in which low AGB values are overestimated and high values are underestimated, which was also reported by other authors (OTA et al., 2014; SILVA et al., 2017b). This may have occurred due to the RF model estimating values by using the average of several decision trees, which tends to underestimate when the estimated values are close to the maximum value of the training data and, similarly, tends to overestimate when they are close to the minimum value of the training data (OTA et al., 2014). Another possible cause, in the case of the present work, was the low number of sample units used for testing.

Moreover, Silva et al. (2017b) pointed out that a disadvantage of RF is that it does not allow the prediction to be extrapolated beyond the trained data, increasing errors when using a new data source, thus corroborating the results of this study. Additionally, Verrelst et al. (2012) found that the performance of validation using machine learning algorithms showed instability, with an increase in errors. Thus, the authors highlighted that it is important to analyze the precision of the trained model through validation instead of just analyzing the training performance.

It should be noted that some factors influenced the variance values not explained by the regression model in the study area. Among these, the discrepancy between the minimum and maximum AGB obtained in the sample units due to the presence of gaps in contrast to those with dense vegetation. There may also have been an incorrect registration of the sample units in the field caused by the dense canopy and high diameter and height of the trees, which prevent the accurate acquisition of coordinates by GNSS. Notably, the signal between the satellite and GNSS receiver may often be completely blocked in these areas, as described by d'Oliveira et al. (2012).

Nevertheless, the RF algorithm has the advantage of being a non-parametric method, which does not need to meet the conditions of the regression, and can be used when there is a small number of observations, thus allowing for good estimates (LI et al., 2017). Therefore, the RF is a suitable method for tropical forest areas, in which often the data are not normal and there is a small number of sample units that are allocated to field research due to difficult-to-access areas that hinder making measurements.

Montaño et al. (2017) highlighted that machine learning techniques can replace allometric models and are a viable and safe alternative for regression analyses. In this context, machine learning algorithms have several advantages that make them an alternative to parametric models. Penner et al. (2013) described that one of the advantages of machine learning algorithms is that they use cross-validation during model development, thus producing robust models. Additionally, machine learning algorithms are preferable when several independent variables are making up the model.

\section{CONCLUSION}

- This study analyzed the use of the RF algorithm to estimate AGB in a tropical forest using LiDAR data. It was possible to infer that the integration of LiDAR data with a machine learning algorithm had the potential to estimate AGB in areas of tropical forest with selective logging, despite the natural condition of the data, which presented a discrepancy between the minimum and maximum AGB of the sample units in the study area.

- In this context, the method employed may be used to assist in the monitoring of native forest areas with selective logging and the managing of said areas. In addition, the same may be applied to other selectively explored tropical forest regions in order to assist in the monitoring of biomass and, consequently, serve as a basis for climate change mitigation policies such as REDD+.

\section{ACKNOWLEDGMENTS}

The authors would like to thank the Brazilian Corporation for Agricultural Research (EMBRAPA) and the United States Forest Service, via the Sustainable Landscapes Brazil Project, which provided the Lidar and forest inventory data. This study was financed by the Coordenação de Aperfeiçoamento de Pessoal de Nível Superior - Brasil (CAPES) - Finance Code 001.

\section{REFERENCES}

ALVAREZ, C. A.; STAPE, J. L.; SENTELHAS, P. C.; GONÇALVES, J. L. M. Modeling monthly mean air temperature for Brazil. Theoretical and Applied Climatology, v. 113, n. 3-4, p. 407-427, 2013.

ALVES, M. V. G.; CHIAVETTA, U.; KOCHLER, H. S.; MACHADO, S. A.; KIRCHNER, F. F. Aplicação de knearest neighbor em imagens multispectrais para a estimativa de parâmetros florestais. Floresta, Curitiba, v. 43, n. 3, p. $351-362,2013$.

FLORESTA, Curitiba, PR, v. 50, n. 4, p. 1873 - 1882, out/dez 2020

Marchesan, J. et.al.

ISSN eletrônico 1982-4688 
ANDERSEN, H. E.; REUTEBUCH, S. E.; MCGAUGHEY, R. J.; D’OLIVEIRA, M. V. N.; KELLER, M. Monitoring selective logging in western Amazonia with repeat lidar flights. Remote Sensing of Environment, v. 151, p. 157-165, 2014.

ASNER, G. P.; KELLER, M.; LENTINI, M.; MERRY, F.; SOUZA JUNIOR, C. Selective Logging and its Relation to Deforestation. Amazonia and Global Change, v. 186, p. 25-42, 2009.

BENÍTEZ, F. L.; ANDERSON, L. O.; FORMAGGIO, A. R. Evaluation of geostatistical techniques to estimate the spatial distribution of aboveground biomass in the Amazon rainforest using high-resolution remote sensing data. Acta Amazonica, Manaus, v. 46, n. 2, p. 151-160, 2016.

CHAVE, J.; RÉJOU-MECHAIN, M.; BÚRQUEZ, A.; CHIDUMAYO, E.; COLGAN, M. S.; DELITTI, W. B. C.; DUQUE, A.; EID, T.; FEARNSIDE, P. M.; GOODMAN, R. C.; HENRY, M.; MARTÍNEZ-YRÍZAR, A.; MUGASHA, W. A.; MULLER-LANDAU, H. C.; MENCUCCINI, M.; NELSON, B. W.; NGOMANDA, A.; NOGUEIRA, E. M.; ORTIZ-MALAVASSI, E.; PÉLISSIER, R.; PLOTON, P.; RYAN, C. M.; SALDARRIAGA, J. G.; VIEILLEDENT, G. Improved allometric models to estimate the aboveground biomass of tropical trees. Global Change Biology, v. 20, n. 10, p. 3177-3190, 2014.

CLARK, M. L.; ROBERTS, D. A.; EWEL, J. J.; CLARK, D. B. Estimation of tropical rain forest aboveground biomass with small-footprint lidar and hyperspectral sensors. Remote Sensing of Environment, v. 115, p. 29312942, 2011.

D'ANNUNZIO, R.; LINDQUIST, E. J.; MACDICKEN, K. G. Global forest land-use change from 1990 to 2010: an update to a global remote sensing survey of forests. Food and Agriculture Organization of the United Nations, 2017. Disponível em: <http://www.fao.org/3/a-i5098e.pdf> Acesso em: 26/06/2018.

D’OLIVEIRA, M. V. N.; REUTEBUCH, S. E.; MCGAUGHEY, R. J.; ANDERSEN, H. E. Estimating forest biomass and identifying low-intensity logging areas using airborne scanning lidar in Antimary State Forest, Acre State, Western Brazilian Amazon. Remote Sensing of Environment, v. 124, p. 479-491, 2012.

GARCIA, M.; SAATCHI, S.; FERRAZ, A.; SILVA, C. A.; USTIN, S.; KOLTUNOV, A.; BALZTER, H. Impact of data model and point density on aboveground forest biomass estimation from airborne LiDAR. Carbon Balance and Management, v. 12, p. 1-18, 2017.

HANSEN, E. H.; GOBAKKEN, T.; NÆSSET, E. Effects of pulse density on digital terrain models and canopy metrics using airborne laser scanning in a tropical rainforest. Remote Sensing, v. 7, n. 7, p. 8453-8468, 2015.

HUDAK, A. T.; STRAND, E. K.; VIERLING, L. A.; BYRNE, J. C.; EITEL, J. U. H.; MARTINUZZI, S.; FALKOWSKI, M. J. Quantifying aboveground forest carbon pools and fluxes from repeat LiDAR surveys. Remote Sensing of Environment, v. 123, p. 25-40, 2012.

INTERNATIONAL SUSTAINABILITY UNIT - ISU. Tropical Forests: A Review. 2015. Disponível em: $<$ https://pcfisu.org/wp-content/uploads/2015/04/Princes-Charities-International-Sustainability-Unit-TropicalForests-A-Review.pdf> Acesso em: 26/07/ 2018.

KUMAR, L.; MUTANGA, O. Remote sensing of above-ground biomass. Remote Sensing, v. 9, n. 9, p. 1-8, 2017.

LI, A.; DHAKAL, S.; GLENN, N. F.; SPAETE, L. P.; SHINNEMAN, D. J.; PILLIOD, D. S.; ARKLE, R. S.; MCLLROY, S. K. Lidar Aboveground vegetation biomass estimates in Shrublands: prediction, uncertainties and application to coarser scales. Remote Sensing, v. 9, p. 1-19, 2017.

MCGAUGHEY, R. J. FUSION/LDV: Software for LIDAR Data Analysis and Visualization. Washington: United States Departament os Agriculture, Forest Service, 2018. 212 p. Disponível em: <http://forsys.cfr.washington.edu/Software/FUSION/FUSION_manual.pdf>. Acesso em: 23/06/2018.

MONTAÑO, R. A. N. R.; SANQUETTA, C. R.; WOJCIECHOWSKI, J.; MATTAR, E.; CORTE, A. P. D.; TODT, E. Artificial Intelligence Models to Estimate Biomass of Tropical Forest Trees. Polibits, v. 56, p. 29-37, 2017.

MURPHY, M. A.; EVANS, J. S.; STORFER, A. S. Quantify Bufo boreas connectivity in Yellowstone National Park with landscape genetics. Ecology, v. 91, p. 252-261, 2010.

OTA, T.; AHMED, O. S.; FRANKLIN, S. E.; WULDER, M. A.; KAJISA, T.; MIZOUE, N.; YOSHIDA, S.; TAKAO, G.; HIRATA, Y.; FURUYA, N.; SANO, T.; HENG, S.; VUTHY, M. Estimation of airborne lidar-

FLORESTA, Curitiba, PR, v. 50, n. 4, p. 1873 - 1882, out/dez 2020.

Marchesan, J. et.al.

ISSN eletrônico 1982-4688

1881

DOI: 10.5380/rf.v50 i4. 66589 
derived tropical forest canopy height using landsat time series in Cambodia. Remote Sensing, v. 6, n. 11, p. 1075010772, 2014.

PAN, Y.; BIRDSEY, R. A.; PHILLIPS, O. L.; JACKSON, R. B. The Structure, Distribution, and Biomass of the World's Forests. Annual Review of Ecology, Evolution, and Systematics, v. 44, p. 593-622, 2013.

PENNER, M.; PITT, D. G.; WOODS, M. E. Parametric vc. Nonparametric LiDAR models for operational forest inventory in boreal Ontario. Canadian Journal of Remote Sensing, n. 39, n. 5, p. 426-443, 2013.

SHAO, Z.; ZHANG, L. Estimating Forest Aboveground Biomass by Combining Optical and SAR Data: A Case Study in Genhe, Inner Mongolia, China. Sensors, v. 16, p. 1-16, 2016.

SILVA, C. A.; HUDAK, A. T.; VIERLING, L. A.; KLAUBERG, C.; GARCIA, M.; FERRAZ, A.; KELLER, M.; EITEL, J.; SAATCHI, S. Impacts of airborne lidar pulse density on estimating biomass stocks and changes in a selectively logged tropical forest. Remote Sensing, v.9, n. 10, p. 1-19, 2017a.

SILVA, C. A.; KLAUBERG, C.; HUDAK, A. T.; VIERlinG, L. A.; JAAFAR, W. S. W. M.; MOHAN, M., GARCIA, M.; FERRAZ, A.; CARDIL, A.; SAATCHI, A. Predicting stem total and assortment volumes in an industrial Pinus taeda L. forest plantation using airborne laser scanning data and Random forest. Forests, Basiléia, v. 8, n. 7, p. 1-17, 2017b.

VERRELST, J.; MUÑOZ, J.; ALONSO, L.; DELEGIDO, J.; RIVERA, J. P.; CAMPS-VALLS, G.; MORENO, J. Machine learning regression algorithms for biophysical parameter retrieval: Opportunities for Sentinel-2 and -3 . Remote Sensing of Envirnonment, v. 118, p. 127-139, 2012. 